\title{
Diversity and Motivation in a Small School: Positioning Self-Access Learning
}

\section{Michelle Jerrems \\ Kanda Jogakuen Junior \& Senior High School \\ Lorna Sachie Asami \\ Kanda Jogakuen Junior \& Senior High School}

\section{Reference Data:}

Jerrems, M., \& Asami, L. S. (2019). Diversity and motivation in a small school: Positioning selfaccess learning. In P. Clements, A. Krause, \& P. Bennett (Eds.), Diversity and inclusion. Tokyo: JALT.

Kanda Jogakuen is a private junior and senior high school for girls that has attracted a diverse student body with a wide range of academic abilities. The structure of the institution, program, and curriculum has had different influences on motivation. The various challenges in enhancing the students' motivation and academic ability led to the establishment of the Kanda Self-Access Learning Center (K-SALC). The center was designed to be a tool to help students foster autonomy and meet a variety of students' needs and goals. In this paper we describe ongoing efforts by teachers at Kanda Jogakuen to better support a diverse group of students in a small school context, particularly focusing on the operation of the K-SALC. The paper gives an account of the establishment of the center and ongoing efforts to evaluate its effectiveness and improve it.

神田女学園は中高一貫の私立女子校で、幅広い学力を持った生徒に対応してきた。学校の体制、プログラム、およびカリキ ユラムは、生徒の学習意欲にさまざまな影響を与えている。生徒の学習意欲と学力を育成する上での様々な課題が、神田女学 園のセルフ・アクセス・ラーニング・センター（K-SALC) の設立につながった。このセンターは、生徒の自律性を育て、多様な生 徒の二ーズや目標を達成するためのツールとなるように設計された。本稿では、特にK-SALCの運営に焦点を当てながら、神

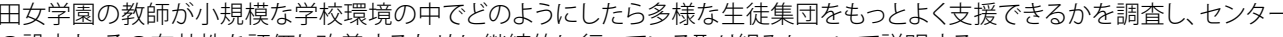
の設立と、その有効性を評価し改善するために継続的に行つている取り組みについて説明する。 anda Jogakuen (hereafter $\mathrm{KJ}$ ) is a small girls' school located in central Tokyo. There Lare approximately 70 students in junior high and 300 students in senior high school. Despite small student numbers, the student body itself is extremely diverse. This diversity has been further magnified with the introduction of a global course in 2015 which attracted students with varied experience and backgrounds. The student body includes students with international school experience and experience living abroad, students with no previous experience learning a foreign language, low ability students, highly academic students, and sports and club-focused students. There are three main streams of study that the students can choose: the advanced course, the global course, and the future course. The global course has a larger number of English classes, and homeroom is conducted in English. The advanced course English classes are fast-paced and focused on university entrance examinations, and the future course focuses more on core English skills and basic grammar.

The small school setting, student diversity, and different courses at $\mathrm{KJ}$ have posed a number of challenges for the English teachers at KJ, who set out to address motivation and autonomy in learners through the newly opened Self-Access Learning Center, known as K-SALC. The implementation and focus of the center was initially motivated by a preliminary study into students' motivation (Jerrems, 2017). There was a lack of motivation and low ability among senior high school students (not only in English, but across all subject areas), particularly in comparison to the junior high students. However, addressing students' motivation through the K-SALC has proved a difficult task. After the establishment of the K-SALC, it was apparent that although the center was beneficial to a small group of students, it was not being utilized by the less motivated and lower-level students.

The discussion will start with a review of the relevant literature on motivation and autonomy and an introduction of the K-SALC. The preliminary study (Jerrems, 2017) will be introduced, and then other factors and sources of data will also be highlighted. Following the investigation of student motivation, the discussion will focus on the 
K-SALC, with a look at the successes of the center, student feedback, and the impact on teacher motivation and the effects of that. Then challenges and possible solutions for the K-SALC will be addressed.

\section{Motivation and Autonomy}

Lack of motivation among students in senior high is not uncommon in Japan. In fact, a lack of motivation stemming from the problematic Japanese educational context and entrance exams is undeniable, so much so that nearly all the leading empirical research on lack of motivation in foreign language learning currently derives from Japan (Ushioda, 2013). According to current theories of motivation, learners' ideal selves can impact upon students' motivation. Dörnyei and Ushioda (2013) identified four conditions for the motivating capacity of ideal learner selves: the learner has a desired future self-image, the future self is different from the current self, the self-image is vivid and detailed, and the future self-image is achievable.

Student motivation is also not the only factor to consider. Teacher motivation is also important to language learning. Teachers who lack motivation can have a dangerous effect on students, and students who perceive their teachers as passionate and enthusiastic will often feel more intrinsically motivated and supported (Dörnyei \& Ushioda, 2013). However, the high pressure of the teaching profession means that this enthusiasm and motivation can wane, often with detrimental effects on student motivation. A teacher's intrinsic motivation will inevitably be influenced by the impact of external conditions and constraints, but if steps can be taken towards creating a more positive environment, this can help to adjust the teacher's attitude (Dörnyei \& Ushioda, 2013).

According to its advocates, autonomy is a precondition for effective learning and increased motivation. If learners succeed in developing autonomy, they become better and more motivated language learners (Benson, 2013). However, to foster autonomy, it is crucial that teachers have a developed understanding of how to do so, and have the necessary resources and support. In running a self-access center, it is unreasonable to expect teachers to foster autonomy in learners if they themselves do not know what it is to be an autonomous learner (Benson, 2013). Teachers also need to provide students with opportunities for reflective dialogue (Gardner \& Miller, 1999), which requires not only a large time commitment from teaching staff, but also the appropriate infrastructure (Benson, 2013). If an institution is prepared to spend a large amount of money on establishing a SALC, it should also provide the staff and support to allow it to function well (Gardner \& Miller, 1999). How an institution establishes, maintains and invests in these resources may result in very different learning outcomes (Cheetham, Elliot, Harper, \& Ito, 2017)

\section{K-SALC}

Before and after the preliminary study was carried out (Jerrems, 2017), there were numerous discussions amongst the staff regarding the difficulties of addressing diversity and motivation at the class level. From these discussions came the suggestion of a self-access learning center (SALC), and the K-SALC was opened in September 2017. As far as we are able to determine, the center is one of the first of its kind to be opened in a secondary school setting in Japan, and has provided some innovative services to the students that they would otherwise not be able to access until university.

In conjunction with the approach of English classes at KJ, the K-SALC gives students access to a more communicative and reflective style of English learning. The students are able to have one-on-one and group lessons with native English teachers, watch movies in English, read books, and practice listening in the center. They are able to talk to teachers about their language learning goals, make study plans, try out resources, discuss problems and progress, and reevaluate their language learning strategies.

When the K-SALC was first established, there were three main goals: foster autonomy, create more opportunities for language study and practice outside of the classroom, and foster better language learning in general.

\section{Evaluation Efforts}

Based on the preliminary study, observation and a follow-up questionnaire, three main factors were identified as having a strong impact on student motivation: differences between the junior and senior high English curriculum and program, students' selfconcept in regards to their English-learner selves, and disparities in English level.

\section{Preliminary Study}

A preliminary study carried out by Jerrems (2017) was set in motion after senior high students had voiced their dissatisfaction with the senior high English program to teachers on numerous occasions. The initial purpose of the study was to understand and interpret students' perceptions of their English ability and motivation, and investigate possible links with communicative English instruction. The data consisted of informa interviews and a questionnaire administered to the students, which included closed 
and open-ended questions. The data was collected to identify patterns and themes and develop further questions and ideas for new curriculum and further research. The group of students was small, not randomly selected, and varied in size for each grade level. All data was originally collected in Japanese and then translated into English.

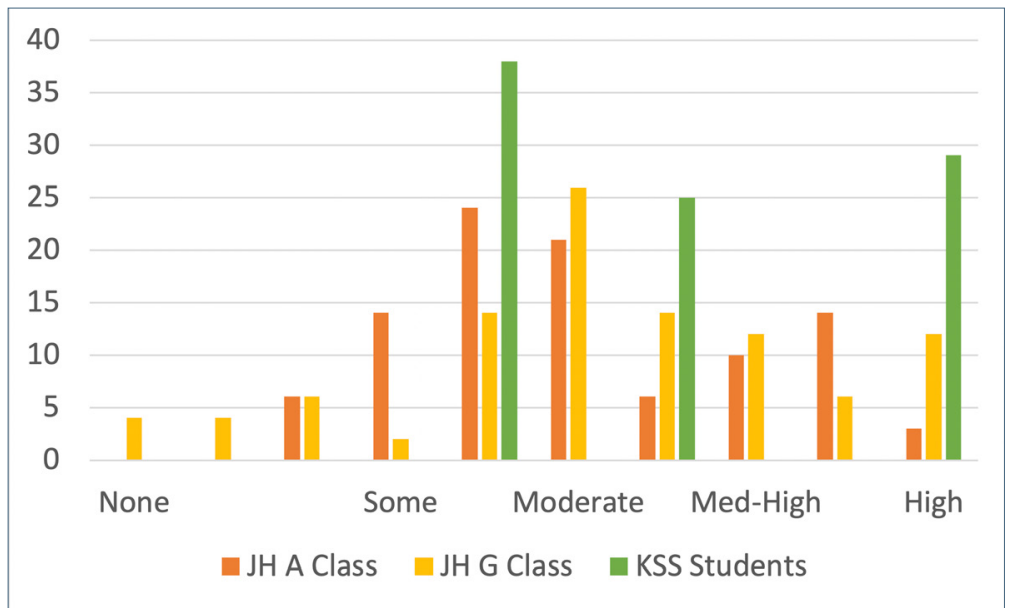

Figure 1. Junior high school students' motivation to study English $(\mathrm{n}=86)$. JH A = Future Course; JH G = Global Course; KSS = Students who attended the Kanda elementary school program.

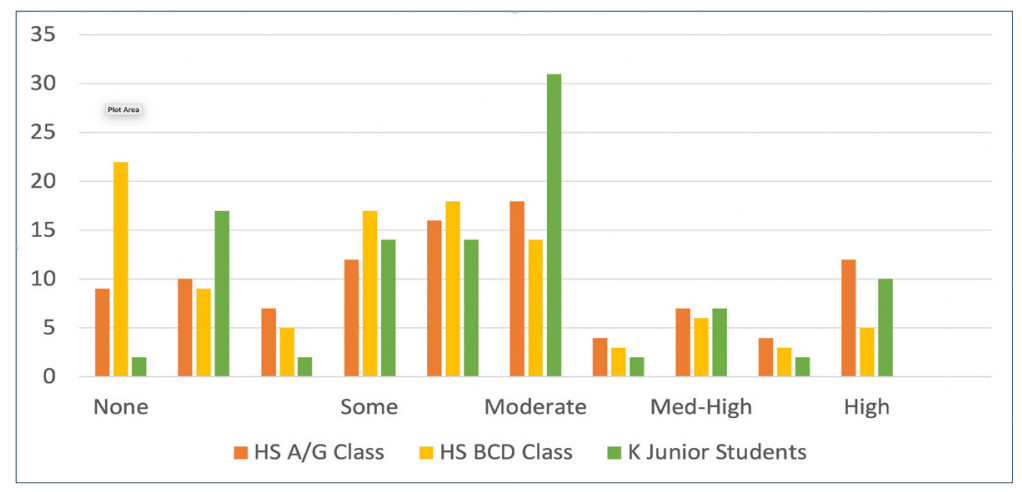

Figure 2. Senior high students' motivation to study English (n = 308). HS A/G = Advanced \& Global Course; HS BCS = Future Course; K Junior = KJ Junior high school.
Figures 1 and 2 illustrate junior and senior high school students' perceptions of their motivation to study English based on the questionnaire (Jerrems, 2017). Students were asked to rate their motivation on a scale from no motivation to high motivation in accordance with the five options indicated in the figures. A high number of junior high students indicated moderate to high levels of motivation, and most senior high students indicated none to moderate.

The difference in motivation between junior high and senior high can be further illustrated by students' comments (translated from Japanese), which suggested that although the junior high students felt that the courses had a positive impact on their English ability, senior high students were dissatisfied with the program. A common theme of the junior high school students' comments was that learning in a communicative style had improved their proficiency ("I managed to pass Eiken pre2 and I have also started being able to talk in English with my teacher. I can also give presentations in English now") and confidence ("I am not afraid to talk to native speakers anymore. I have to speak in English, but I now understand that my English does not need to be perfect in order to communicate"). Contrastingly, senior high students complained of a lack of balance in the course ("At junior high, we did listening, reading, penmanship and grammar. However, senior high is just grammar, so I don't feel like I have any speaking ability"), and that they no longer enjoyed studying English ("In junior high we had fun talking and learning with the native teachers. Senior high English is not fun").

\section{Observations and Follow-Up Questionnaire}

Through observations and a follow-up questionnaire, additional information was gathered in regards to students' self-concept as language learners and language levels. Differences in self-concept were noticed by K-SALC staff working one-on-one with students in the K-SALC. As part of the global course, students have a larger number of more intensive English courses than other students: morning and afternoon homeroom in English and special one-on-one lessons to prepare for study abroad. All junior high and senior high global students must undertake a compulsory study abroad as part of the global program.

It was recognized in the one-on-one K-SALC sessions that for students who were about to undertake a study-abroad program, motivation was far more practical as they had clear goals for what they wanted to achieve and when they wanted to achieve it, meeting Dörnyei and Ushioda's (2013) conditions. However, for students who were not in the global program, it was quite difficult for them to visualize their ideal self as an English language learner. Not only did this create a stumbling block in regards to their 
motivation to study English, but comparing themselves to the more goal-driven global students caused them to lose even more motivation.

This loss of motivation was also exacerbated by disparities between student English levels, which is the third factor identified as affecting students' motivation. This is illustrated in Table 1. This data was taken from a follow-up questionnaire given to students in two junior high courses at the end of their 2nd year: the global course and future course (Jerrems \& Asami, 2018).

Table 1. English Level Disparity: Junior High School 2nd-Year Eiken Levels

\begin{tabular}{lcc}
\hline Eiken test level & \multicolumn{2}{c}{ \% of Students who passed Eiken tests } \\
\cline { 2 - 3 } & Global Course & Future Course \\
\hline Pre-1 & 5 & 0 \\
2 & 20 & 0 \\
Pre-2 & 30 & 0 \\
3 & 10 & 0 \\
4 & 30 & 30 \\
5 & 5 & 60 \\
None & 0 & 10 \\
\hline
\end{tabular}

As highlighted in the table, nearly $60 \%$ of the global class students had already reached at least pre-2 Eiken level, but more than $60 \%$ of the students in the future course had not achieved more than a level 5 . In the small school context, there were many opportunities for students to compare themselves to one another. Depending on the course that the students took, there was also a growing difference in their English ability over time. Of course, in the global course there was a higher number of students who started with a higher English ability. This was mainly due to the fact that students in the global course often had already formed an interest in studying English or foreign cultures, and for this reason had chosen the global course. However, over time and due to the nature of the course - the intensity and number of English classes-a large majority of the global students achieved a high level of English competence, regardless of their level when they entered. This in turn had a negative impact on the future class students' motivation, when they compared themselves with global class students, whose English level seemed unattainable in the future course setting.

\section{Success of the K-SALC and Student Feedback}

One year after the opening of the K-SALC, a follow-up survey was administered to measure the success of the center and the students' usage and impressions of the facility (Jerrems \& Asami, 2018). Students were asked about how often they used the K-SALC and to select the answer that most appropriately represented their usage patterns. Figures 3 and 4 illustrate the answers for both junior and senior high students. Students' answers have been translated from Japanese to English.

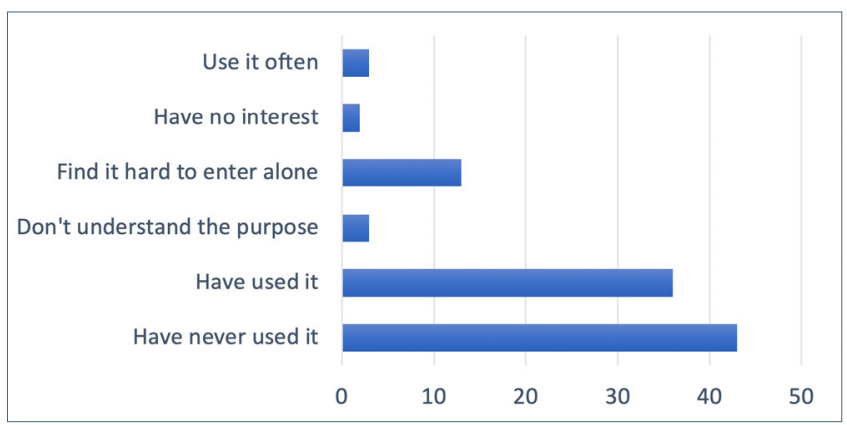

Figure 3. Senior high students' usage of the K-SALC.

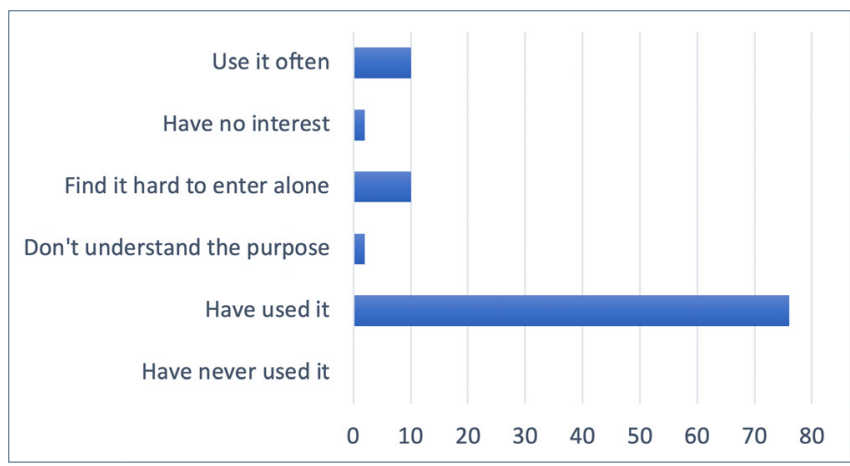

Figure 4. Junior high students' usage of the K-SALC. 
These results show that nearly half of the senior high students reported never having used the facility. Given that the least-motivated students identified in the preliminary study (Jerrems, 2017) were senior high school students, this was a disappointing yet unsurprising finding. Junior high students on the other hand, as discussed previously, were more motivated due to the nature of the English programs and courses. The programs in the junior high also gave these students more opportunities to visit and make use of the K-SALC.

Students' comments, particularly those of senior high students, also highlighted the fact that they still did not understand the purpose of the facility ("I don't really understand K-SALC's purpose"), or how they could use it ("I've never been to the K-SALC, so I don't really know anything about it"). Other students wanted to use the facility for other activities: "I would like a space where I can study any subject I want, not just languages." "I would like to do more cultural exchange activities. I want to meet people from a variety of different countries." Finally, there were comments about the type of support provided in the center: "I would like to have lessons with Japanese teachers of English. There are things that I cannot understand when a native English teacher explains in English."

Challenges and Possible Solutions in the Classroom and K-SALC After the 2018 follow-up survey, underlying causes and possible solutions were investigated. There were many discussions with teaching staff and students, and it became apparent that despite the best intentions for the K-SALC, facility infrastructure and staffing were lacking and detracting from the success of the center. This included teacher overwork and lack of motivation, lack of understanding of the facility among teachers and administrators, lack of reflective dialogue with students and underdevelopment of K-SALC curriculum and support materials. In order to address these issues, four strategies have been suggested: management of the well-being, motivation, and enthusiasm of teachers; ongoing professional development; ongoing reflective dialogue between teachers and students (in and outside the classroom); and curriculum development and reevaluation.

Staffing has proved to be one of the major difficulties for the K-SALC. Although university SALCs often have specialized staff devoted full-time to the facility, that is not the case in this small school context. A limited number of native English-teaching staff must run the center in addition to their full class loads and home room duties. This tight schedule is put under further pressure due to the nature of the students' timetables since (unlike university students) they have no free periods until 3:30 p.m. or later.
The teachers who run the K-SALC need to manage one-on-one sessions with students, provide study advice and feedback, show students how to use the center, update and manage resources, and manage ongoing programs for the center, all in a very limited amount of time. As a result of these restrictions and pressure to manage the K-SALC effectively, teachers in the center voiced their dissatisfaction, and lack of motivation amongst the teachers running the K-SALC became apparent.

It is vital to provide more support and resources to the teachers running the K-SALC. At present, suggestions and adjustments have been put forward for changes in the management structure, staff numbers and curriculum development, and a new staffing structure will be put in place in the K-SALC in the next academic year. This will include at least one staff member dedicated to organization and curriculum design of the center and more hours made available for K-SALC management and teaching staff in their schedules to dedicate to the center.

To positively influence teacher motivation, it is vital to have ongoing professional development (Fives \& Alexander, 2004). To date, staff members have already created seminar opportunities and there have been ongoing seminars on autonomy, the purpose of the K-SALC, and student counseling and support. So far, however, these seminars have been targeted at English-teaching staff. This needs to expand to seminars for all faculty, departments, and administration.

There also needs to be more reflective dialogue. In most SALCs this is provided by ongoing sessions with a learning advisor. However, this service is not available at the $\mathrm{K}-\mathrm{SALC}$, and due to this lack of support and ongoing feedback, students often lose momentum and motivation with their individual study plans. This is another area that staff members are struggling to manage and as a consequence has contributed to a loss of staff motivation.

There are however, several things that can be done to help provide more feedback for students. Student support and advising could take place in the classroom and homeroom (Benson, 2013). Advising and reflection can also be done through email, letters, journals, study plans, and self-assessment (Gardner \& Miller, 1999). Some of these ideas have already been implemented, including study plans and self-assessment. However, these methods will again put further time pressures on the staff and will need to be managed carefully.

The final challenge facing the K-SALC is the lack of curriculum development and evaluation. Because of time and scheduling pressures, it has been difficult for K-SALC staff to efficiently manage the facility's resources and as a result resources are still incomplete and underdeveloped. For the K-SALC to provide a more well-rounded, 
easy-to-use service there is a need for greater organization (Gardner \& Miller, 1999) and greater connection among the junior high, senior high, and K-SALC English programs. Students also need more information and support on how to use K-SALC resources and study independently (Benson, 2013), and effective learning modules need to be created (Mynard \& Stevenson, 2017). It is the hope of the K-SALC staff that with the restructuring of staffing in the new academic year, there will be more time scheduled for the development of these resources.

\section{Conclusion}

A lack of motivation, particularly among senior high students, was the initial spark for the preliminary study. The preliminary study confirmed what was largely already recognized, but also led to the development of the K-SALC, further evaluation, and finally a recognition of a lack of motivation amongst teachers. Student motivation and teacher motivation are intertwined in such a way that it is hard to discuss one without the other. It can be said that all teachers set off on a new teaching endeavor or project with the best of intentions and high levels of motivation (Dörnyei \& Ushioda, 2013). However, constraints on teaching practice can lead to cynicism and resignation, and teachers need to understand the constraints upon their practice but, rather than feeling disempowered, they need to be empowered by finding the spaces and opportunities to maneuver (Benson, 2013).

Despite establishing the K-SALC with the aim of positively influencing motivation, the project is still far from what one might describe as a success. However, if ongoing evaluation of the constraints and successes of the K-SALC and the wider English programs continue, there is always the opportunity for positive change. Many positive steps have already been taken, including the opening of the K-SALC itself, improvements in staffing structure, and provision of more professional development opportunities. This in turn will provide more support for staff and boost teacher motivation. It is the hope of the authors and staff that this can be continued, and that the results will be evident in the students' motivation, study skills, and language ability.

\section{Bio Data}

Michelle Jerrems has been working at Kanda Jogakuen for 6 years. She is currently interested in motivation, autonomy, self-access and language learning. <michelle.shelly. jerrems@gmail.com>

Lorna Asami has been a full-time teacher at Kanda Jogakuen for 3 years. She enjoys being involved with the students at her school in various clubs and by helping them with their English in the school's new self-access center.

\section{References}

Benson, P. (2013). Teaching and researching autonomy (2nd ed.). New York, NY: Routledge.

Brown, H. D. (2014). Teaching by principles: An interactive approach to language pedagogy (6th ed.). New York, NY: Pearson Education.

Cheetham, C., Elliot, M., Harper, A., \& Ito, M. (2017) Accessibility and the promotion of autonomous EFL reading. Studies in Self-Access Learning Journal, 8(1), 4-22.

Dörnyei, Z., \& Ushioda, E. (2013). Teaching and researching motivation (2nd ed.). New York, NY: Routledge.

Gardner, D., \& Miller, L. (1999). Establishing self-access: From theory to practice. Oxford, England: Oxford University Press.

Fives, H., \& Alexander, P. (2004). How schools shape teacher efficiency and commitment: Another piece in the achievement puzzle. In D. M. Mclnerney \& S. Van Etten (Eds.), Big theories revisited (pp. 329-360). Greenwich, CT: Information Age Publishing.

Jerrems, M. (2017, December). All English instruction: Implications for students' motivation and communicative competence. Paper presented at Hiroshima JALT Conference, Hiroshima, Japan.

Jerrems, M., \& Asami, L. (2018, June). Ideals for diversity and motivation in a small school context. Poster presented at PLL3 Conference, Waseda University, Tokyo, Japan.

Mynard, J., \& Stevenson, R. (2017). Promoting learner autonomy and self-directed learning: The evolution of a SALC curriculum. Studies in Self-Access Learning Journal, 8(2), 169-182.

Ushioda, E. (2013). Foreign language motivation research in Japan: An 'insider' perspective from outside Japan. In M. Apple, D. Da Silva, \& T. Fellner (Eds.), Language learning motivation in Japan (2nd ed., pp. 1-14). New York, NY: Multilingual Matters. 